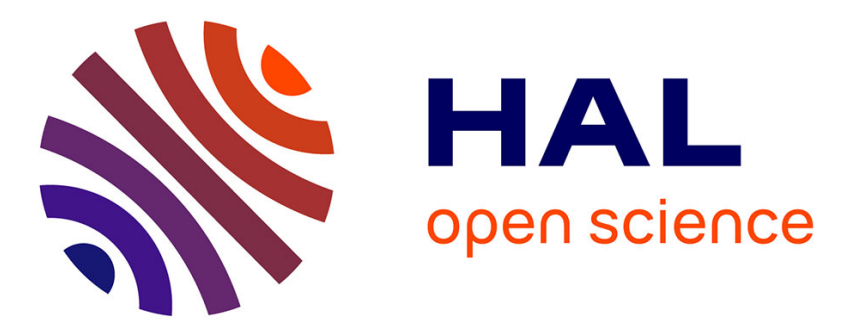

\title{
Effect of agricultural practices and coastal constraints on soil microbial functional properties in Mediterranean olive orchards
}

\author{
N. Boukhdoud, R Gros, T. Darwish, Anne Marie Farnet da Silva
}

\section{- To cite this version:}

N. Boukhdoud, R Gros, T. Darwish, Anne Marie Farnet da Silva. Effect of agricultural practices and coastal constraints on soil microbial functional properties in Mediterranean olive orchards. European Journal of Soil Science, 2016, 67 (4), pp.470-477. 10.1111/ejss.12347 . hal-02068523

HAL Id: hal-02068523

https://hal.science/hal-02068523

Submitted on 15 Mar 2019

HAL is a multi-disciplinary open access archive for the deposit and dissemination of scientific research documents, whether they are published or not. The documents may come from teaching and research institutions in France or abroad, or from public or private research centers.
L'archive ouverte pluridisciplinaire HAL, est destinée au dépôt et à la diffusion de documents scientifiques de niveau recherche, publiés ou non, émanant des établissements d'enseignement et de recherche français ou étrangers, des laboratoires publics ou privés. 


\title{
Effect of agricultural practices and coastal constraints on soil microbial functional properties in Mediterranean olive orchards
}

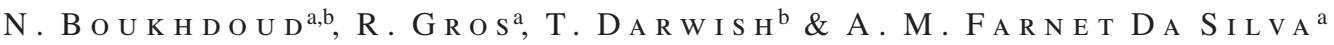 \\ anstitut Méditerranéen de Biodiversité et d'Ecologie Marine et Continentale, UMR 7263, Aix Marseille Université, CNRS, IRD, Avignon \\ Université, Campus l'Etoile, 13397 Marseille cedex 20, France, and ${ }^{\mathrm{b}}$ Center for Remote Sensing, CNRS, PO Box 11-8281, Beirut, Lebanon
}

\begin{abstract}
Summary
This research examines how agricultural practices commonly used in Lebanese olive tree orchards (no-tillage, co-culture with Vicia sativa L. var. sativa and conventional tillage) affect soil microbial and chemical characteristics, and whether this depends on geographical context (coastal or inland areas). Four coastal and four inland sampling sites were selected, and at each site three practices were considered (one practice per plot). For each plot $\left(200 \mathrm{~m}^{2}\right), 20$ soil samples were taken and homogenized to obtain a composite sample from which soil was characterized chemically and microbiologically. Differences in chemical properties (smaller $\mathrm{N}$ content and alkyl $\mathrm{C}$ fraction in the coastal area) depended on geographical location rather than on agricultural practices. For microbial properties, catabolic structure varied with geographical location; the index of catabolic diversity was larger in the coastal area. Importantly, the basal respiration was similar in both areas although the soil contained less nitrogen $(\mathrm{N})$ in the coastal area. The negative effect of conventional tillage on microbial functioning of the soil was observed only in relation to geographical location. We found that this effect was reduced by co-culture, for example with Vicia sativa L. var. sativa. Our study reveals that geographical location affects how agricultural practices affect soil properties (in the coastal area, enhanced mineralization of labile $\mathrm{C}$ and change in microbial catabolic profile). This suggests that soil management should take into account the environmental conditions specific to coastal areas, which enhance the adverse effects of conventional tillage. Consequently, this type of management should not be implemented in coastal areas of the Mediterranean.
\end{abstract}

\section{Highlights}

- What are the appropriate practices for olive trees under coastal constraints?

- Coastal-specific constraints were the main factors controlling microbial communities.

- Agricultural practices affected enzyme activities depending on distance from the sea.

- Tillage should not be implemented in coastal areas of the Mediterranean.

\section{Introduction}

Olive trees (Olea europaea L.) are among the longest cultivated fruit trees in the Mediterranean basin (Ferrise et al., 2013), where olive oil has been produced for thousands of years. Their cultivation is an important socio-economic feature and a Mediterranean cultural symbol. Mediterranean soil is known to be poor in organic matter and subject to erosion (Kosmas et al., 1997). In this context, olive orchards contribute to ecosystem services by improving soil conservation. The main constraint is summer drought (Castro et al., 2008; Sofo et al., 2008), but coastal zones also experience windy conditions and higher temperatures, in addition to factors such as sea spray, all of which induce osmotic stress, increase desiccation and affect microbial functioning of the soil. Climatic projections for the coming decades suggest an increase in the number of heat waves and drought periods in the Mediterranean region, which is considered to be particularly sensitive to these expected extreme conditions (Giorgi \& Lionello, 2008). Appropriate management is clearly required to maintain soil quality for this typical Mediterranean crop. 
Inappropriate agricultural practices can have a substantial effect on chemical properties of soil (i.e. salinity, $\mathrm{pH}$, nutrient content and balance, and $\mathrm{C} / \mathrm{N}$ ratio) (Nieto et al., 2012) and can affect the $\mathrm{C}$ and $\mathrm{N}$ cycles governed by soil microbial communities. Previous studies have shown that certain agricultural practices favour carbon sequestration in the soil of olive tree orchards (Sofo et al., 2005) and that olive tree biomass has a long-term carbon storage capacity (Nieto etal., 2012). Weed control in olive tree orchards is, for instance, traditionally based on tillage. Tillage is also considered necessary in the topsoil to reduce compaction and improve water infiltration temporarily. Chemical treatments are commonly used to limit olive grove pests such as Bactrocera oleae (Rossi) (olive fruit fly), especially in the coastal area where more pronounced heat favours the development of this pest. Recent studies have focused on improving soil management, with cover crops under olive trees, for instance, to increase soil organic matter and improve the structure and fertility of soil (Castro et al., 2008). In Lebanon, some farmers have opted for conservation agriculture by planting Vicia sativa L. var. sativa (Fabaceae family) under olive trees to improve nitrogen fixation and soil fertility to maintain or even increase crop yields (Chalak et al., 2011).

Our study aims to understand how common agricultural practices in Lebanese olive tree orchards, such as no-tillage, co-culture with Vicia sativa L. var. sativa and conventional tillage, affect functioning of the soil. In addition, we investigated how responses of both soil chemical and microbial properties depend on the interaction between geographical location and practice. To this end, we characterized both the chemical (total $\mathrm{C}$ and $\mathrm{N}, \mathrm{CaCO}_{3}$ and organic matter quality by solid-state NMR of ${ }^{13} \mathrm{C}$ ) and the microbial (catabolic structure, extracellular enzyme activities, basal respiration and biomass) properties of the soil according to the geographical location (i.e. coastal or inland area). We hypothesized that coastal environments, where hydric, thermic and osmotic stresses are amplified (mainly because of wind conditions and exposure to sea spray), might affect the structure of microbial communities differently and lead to differences in both $\mathrm{C}$ and $\mathrm{N}$ dynamics and in the soil's functional responses to management.

\section{Materials and methods}

\section{Sampling sites and experimental design}

The study was carried out in El Koura (north Lebanon), a region with homogeneous geomorphological and pedological properties. Its climate is typically Mediterranean and characterized by an average annual rainfall of $900 \mathrm{~mm}_{\text {year }}^{-1}$ and mean temperature of $16^{\circ} \mathrm{C}$. The region has a long tradition of olive farming. Two areas located $200 \mathrm{~m}$ (coastal, C) and $6 \mathrm{~km}$ (inland, I) from the coastline were chosen. Average altitudes of the coastal and inland areas are 75 and $285 \mathrm{~m}$ above sea level, respectively. In each area (coastal and inland), four independent sites (coastal area, $34^{\circ} 21^{\prime} 38^{\prime \prime} \mathrm{N}$, $35^{\circ} 44^{\prime} 31^{\prime \prime} \mathrm{E}$; inland area, $34^{\circ} 18^{\prime} 35.2^{\prime \prime} \mathrm{N}, 35^{\circ} 48^{\prime} 27.8^{\prime \prime} \mathrm{E}$ ) from 1 to $3 \mathrm{~km}$ apart were chosen for their homogeneous pedoclimate using the soil database and map from the Center for Remote Sensing (CNRS-Lebanon) (Darwish et al., 2006). The pedoclimatic characteristics were mean annual temperature $\left(10-15^{\circ} \mathrm{C}\right.$ and above $15^{\circ} \mathrm{C}$ in inland and coastal areas, respectively) and mean annual precipitation $(930 \mathrm{~mm}$ per year for the inland area and $900 \mathrm{~mm}$ per year for the coastal area). Other characteristics included aspect (W), slope (0-5\%), soil type (calcic Luvisol in the coastal area or Luvisol in the inland area according to the IUSS Working Group WRB (2006)) and main soil properties (depth ranged from 70 to $100 \mathrm{~cm}, \mathrm{pH}$ from 7 to 7.5 , clay content from 200 to $300 \mathrm{~g} \mathrm{~kg}^{-1}$, $\mathrm{CaCO}_{3}$ concentration from 120 to $410 \mathrm{~g} \mathrm{CaCO}_{3} \mathrm{~kg}^{-1}$ and sandy loam texture).

The four sampling sites were selected at random in each area (coastal and inland). For each site, three management practices in 20-year-old olive tree orchards were considered: (i) no-tillage, where a cover of natural grass was maintained for 4-5 years, (ii) co-culture for 4-5 years at least with Vicia sativa L. var. sativa sown after conventional tillage and (iii) conventional tillage annually over the previous $4-5$ years. For each site in each area, four plots per practice were selected at random to give a total of 24 samples: 4 plots $\times 3$ practices $\times 2$ areas. For each practice, sampling plots with similar tree density were selected and delimited at each site to reduce the effect of borders.

We sampled the soil in the first week of April 2013. For each plot $\left(200 \mathrm{~m}^{2}\right)$, we took 20 soil samples at randomly selected sites by shovel at $0-10-\mathrm{cm}$ depth. The samples were mixed thoroughly to homogenize them to obtain a composite sample. Soil samples were taken from rows and inter-rows (ten each), excluding the area beneath the canopy. The soil was sieved $(<2 \mathrm{~mm})$ to remove plant roots, fauna and debris and hand mixed. Soil samples were stored at $4^{\circ} \mathrm{C}$ before the determination of microbial activities.

\section{Chemical and microbial characterization of the soil}

Chemical characterization. To measure $\mathrm{pH}$ and electrical conductivity, $4 \mathrm{~g}$ of soil was mixed with $40 \mathrm{ml}$ of deionized water (30 minutes) and measured with a Metrohm $744 \mathrm{pH}$ meter for $\mathrm{pH}$ and a DIST three electrode (HANNA Instruments, Limena, Italy) for electrical conductivity (EC). Soil samples were oven-dried for 48 hours at $90^{\circ} \mathrm{C}$ until the weight remained constant; water content $\left(\mathrm{g} \mathrm{kg}^{-1}\right)$ was then deduced from the samples' weights before and after drying. To measure total organic carbon (TOC) and total nitrogen concentration (TN), air-dried soil was crushed in a blender and analysed by combustion in an Elemental Analyzer, FlashEA 1112 (Thermofisher, Villebon-sur-Yvette, France). Determination of calcium carbonate $\left(\mathrm{CaCO}_{3}\right)$ in soil was based on the release of $\mathrm{CO}_{2}$ after the addition of $\mathrm{HCl} 4 \mathrm{~N}$ using the calcimeter Bernard method. Organic carbon was calculated as the difference between total $\mathrm{C}$ content and carbonate $\mathrm{C}$ content. The quality of organic matter was determined by solid-state nuclear magnetic resonance (NMR) of ${ }^{13} \mathrm{C}$, and spectra were obtained with a Bruker Avance (Rheinstetten, Germany) $400 \mathrm{MHz}$ NMR spectrometer that operates at a ${ }^{13} \mathrm{C}$ resonance frequency of $106 \mathrm{MHz}$ and uses a Bruker double-bearing probe. The ${ }^{13} \mathrm{C}$ chemical shifts were referenced to tetramethylsilane (at $0 \mathrm{ppm}$ ) and calibrated with a glycine carbonyl signal set at 176.5 ppm. Following Baldock et al. (1992), the ${ }^{13} \mathrm{C}$ NMR spectra, 
obtained from samples of $80 \mathrm{mg}$ of dry ground soil spun at a magic angle spinning (MAS) rate of $10 \mathrm{kHz}$, were divided into four chemical shift regions: alkyl C (0-45 ppm), O-alkyl C (45-112 ppm), aromatic C (112-160 ppm) and carboxyl C (160-185 ppm). Two ratios were calculated from the NMR of ${ }^{13} \mathrm{C}$ data: the aromaticity ratio (the sum of aromatic- $\mathrm{C}$ to the sum of all regions except carboxyl C) and the humification ratio (alkyl C to O-alkyl C).

Microbial properties. The microbial catabolic structures were determined with BIOLOG ${ }^{\circledR}$ EcoPlates (BIOLOG Inc., Hayward, CA, USA) following Garland \& Mills (1991). Briefly, $4 \mathrm{~g}$ dry weight equivalent of a subsample was added to $50 \mathrm{ml}$ of sterile $0.1 \%$ Na-pyrophosphate solution ( $\mathrm{pH} 7)$. The mixture was then shaken on an orbital shaker for 20 minutes, and centrifuged at $500 \mathrm{~g}$ for 10 minutes at $4^{\circ} \mathrm{C}$ to obtain a microbial suspension. Exactly $1 \mathrm{ml}$ of supernatant was diluted into $99 \mathrm{ml}$ of sterile saline solution $(0.85 \%$ $\mathrm{NaCl}$ ), hand mixed for $30 \mathrm{~s}$ and left to stand for 10 minutes. For each sample, a 125- $\mu \mathrm{l}$ aliquot of the diluted solution was added to each of 32 wells ( 31 substrates plus a control) in a BIOLOG ${ }^{\circledR}$ EcoPlate. The plates were incubated at $25^{\circ} \mathrm{C}$ for 48 hours and the absorbance was read at $590 \mathrm{~nm}$ with a microplate reader (Infinite 200, Tecan, Männedorf, Switzerland). To measure the functional diversity (FD), Shannon's diversity index, $H^{\prime}$ (Shannon \& Weaver, 1949), was calculated (Zak et al., 1994) from:

$$
H^{\prime}=-\sum_{i=1}^{s} p_{i} \ln p_{i},
$$

where $p_{i}$ is the ratio of colour development of well $i, i=1,2, \ldots, S$, to the sum of colour development of all positive wells and $S$ is the number of wells. The average capacity of the microbial cultivable community in each microplate to use the 31 substrates was assessed by calculating the average well-colour development (AWCD) as follows:

$$
\mathrm{AWCD}=\sum_{i=1}^{N} \frac{\mathrm{OD}_{i}}{31},
$$

where OD is the optical density for each well and 31 is the number of substrates.

The basal and substrate-induced respirations were measured as described by Anderson \& Domsch (1978). Microbial respiration was expressed as $\mu \mathrm{g}$ of $\mathrm{C}$ formed as $\mathrm{CO}_{2} \mathrm{~g}^{-1}$ dry soil hour ${ }^{-1}$. Substrate-induced respiration rates were converted into microbial biomass with equations given by Beare et al. (1990). Enzyme activities of tyrosinase, cellulase, protease, urease and lipase were quantified directly in the soil samples. Tyrosinase activity was based on the oxidation of tyrosine to L-Dopa $\left(\varepsilon^{\mathrm{M}}=3400 \mathrm{M}^{-1} \mathrm{~cm}^{-1}\right)$ following Saiya-Cork et al. (2002). Cellulase activity was measured with the Somogy-Nelson method modified by Farnet et al. (2010b) with carboxymethyl cellulose as substrate. Urease activity was measured as described by Kandeler \& Gerber (1988) based on the determination of $\mathrm{NH}_{4}{ }^{+}$after urea hydrolysis. Lipase activity was measured in accordance with Farnet et al. (2010a) with $p$-nitrophenyl ( $p N P$ ) laurate as substrate. Protease activity was determined using the method of Ladd \& Butler (1972).

\section{Statistical analyses}

Two-way analyses of variance (ANOVAs) were performed taking into account geographical location (coastal and inland), agricultural practices (no-tillage, tillage and Fabaceae co-culture) and their interactions, followed by Fisher's least significant difference (LSD) test. A Student's $t$-test was also used to determine whether means for the same practice in the two geographical areas were significantly different. The normality and homogeneity of the variances were determined on the residuals from the regression model with the Shapiro-Wilk and Levene tests, respectively. Data were transformed to common logarithms, $\log _{10}$, when necessary to meet the requirements of normality and homogeneity of variance for ANOVA. Principal component analysis (PCA) was used to explore the effects of agricultural practice and geographical context on the catabolic structure of microbial communities from Biolog ${ }^{\circledR}$. Absorbance values from the 31 substrates obtained for $\mathrm{AWCD}=0.5$ were centred and the PCA was done on the covariance matrix. The proportion of the variance in the data explained by each principal component was calculated and the strongly correlated substrates $(r>0.5$ or $<-0.5)$ for a given axis were used to explain its meaning. The mean scores (on PC1 and PC2) of the four plots and standard errors were calculated to define each projection point (centroid). Statistical analyses were carried out with XLSTAT-Pro 7.5 (Addinsoft, Paris, France) and differences were considered significant at $P<0.05$.

\section{Results and discussion}

The two-way analyses of variance did not show any significant effect of agricultural practice, when considered alone or in interaction with the area, on total $\mathrm{N}$ content, $\mathrm{C} / \mathrm{N}$ ratio and organic matter quality described by NMR data (Table 1). Surprisingly, the type of agricultural practice implemented did not modify the soil chemical properties significantly in the two areas studied. Tillage has been reported to have a negative effect on soil quality, whereas cover crops have the opposite effect, which is good for soil conservation (Hernández et al., 2005; Ramos et al., 2010; Nieto et al., 2013). In olive orchards, for example, tillage usually enhances mineralization of labile $\mathrm{C}$, leading to a decrease in soil organic carbon in the top few centimetres $(0-5 \mathrm{~cm})$, whereas a cover crop results in $\mathrm{C}$ storage in the soil (Nieto et al., 2012). Cover crops, however, are usually effective in reducing run-off and the loss of soluble nutrients from the soil after precipitation, which modifies the soil ion (such as $\mathrm{K}^{+}$ and $\mathrm{P}^{+}$) concentrations (Gómez et al., 2009).

Our results indicate that geographical location strongly affects the chemical characteristics of the soil in the two areas. Conductivity was larger in the soil from the coastal area $\left(130.5 \mu \mathrm{S} \mathrm{cm}^{-1} \pm 6.4\right.$ (coast), $69 \mu \mathrm{S} \mathrm{cm}^{-1} \pm 4.9$ (inland)), which indicates the effect on the soil of exposure to sea-spray and the functional processes in soil that result from osmotic stress. Organic matter content also differed depending on distance from the sea (Tables 1 and 2): total nitrogen was significantly less $(P<0.05)$ in the coastal area, whereas there was no difference in organic carbon content between geographical areas. Consequently, the $\mathrm{C} / \mathrm{N}$ ratio was significantly 
Table 1 Summary of the analysis of variance for certain soil chemical and microbial markers to test the effect of the distance from the sea, the agricultural practices and their interaction

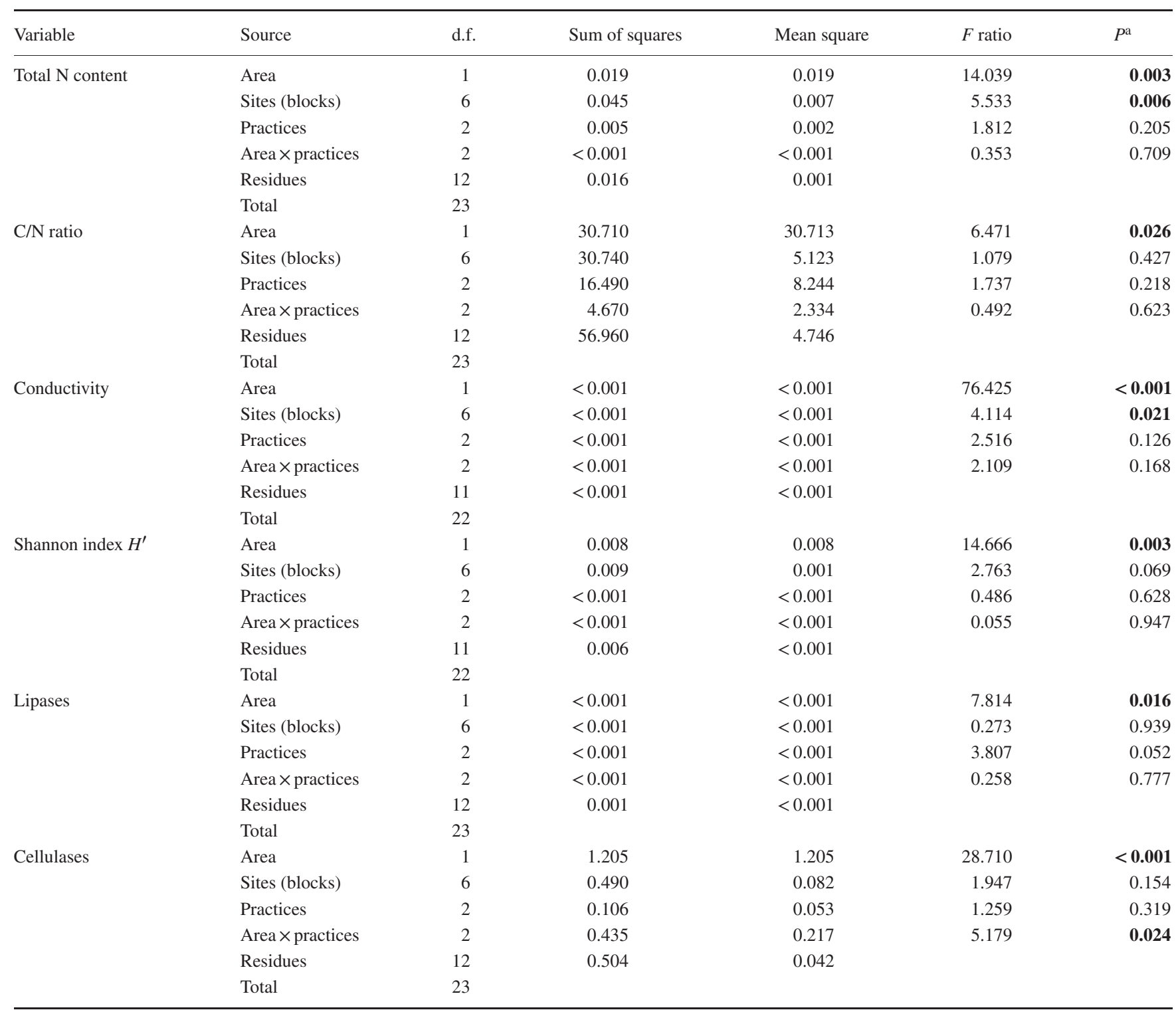

${ }^{\mathrm{a}}$ Values shown in bold are significant for $P<0.05$.

larger $(P<0.05)$ in the coastal area (Table 1$)$. Salinity can reduce nitrogen fixation in soil; for example, nitrogen concentrations decrease in soil according to the degree of salinity of the water used for irrigation. An effect of salinity on the mineral nitrogen production by microbiological activities in the soil through organic matter transformation has been shown under these conditions (Van Hoorn et al., 2001).

Figure 1 shows the results of the PCA for six combinations of area and management (based on the profiles of microbial substrate use) plotted on the first two principal components. The first two principal components (PCs) account for $46 \%$ of the variation in the data; PC1 accounts for $29.2 \%$ and PC2 for $16.9 \%$ (Table 3). Figure 1(a) shows a plot of the principle component scores in the plane of the first two components. It illustrates the discrimination between inland and coastal soil on PC1, which indicates a change in the structure of catabolic diversity that depends on geographical location. The coastal samples (black circles) are on the right-hand side (rhs) of this axis, whereas the inland sites (white circles) are on the left-hand side (lhs).

Figure 1(b) gives the plot of the correlation coefficients within a circle of unit radius in the plane of the first two principal axes. It shows that microbial community level physiological profiles (CLPPs) for tillage in the coastal area (rhs) are characterized by a large use of glycogen $(r>0.5)$, a labile polysaccharide, whereas in the inland area D-cellobiose and D-mannitol are strongly and positively correlated $(r>0.5)$ with no-tillage and Fabaceae 
Table 2 Soil chemical properties for inland and coastal areas for the three agricultural practices (means \pm standard error, $N=4$ )

\begin{tabular}{lrr}
\hline Variable & Inland area & Coastal area \\
\hline Organic C content / $\mathrm{g} \mathrm{C} \mathrm{kg}^{-1}$ & $20.6 \pm 1.8$ & $18.2 \pm 1.6$ \\
Total N concentration / $\mathrm{g} \mathrm{N} \mathrm{kg}^{-1}$ & $\mathbf{2 . 2} \pm \mathbf{0 . 1}$ & $\mathbf{1 . 6} \pm \mathbf{0 . 2}$ \\
C/N ratio & $\mathbf{9 . 3} \pm \mathbf{0 . 5}$ & $\mathbf{1 1 . 6} \pm \mathbf{0 . 8}$ \\
Alkyl C & $\mathbf{2 4 . 6} \pm \mathbf{2 . 1}$ & $\mathbf{1 9 . 8} \pm \mathbf{2 . 2}$ \\
O-alkyl C & $28.6 \pm 3.0$ & $26.4 \pm 2.1$ \\
Methoxyl C & $11.9 \pm 1.6$ & $11.5 \pm 2.4$ \\
Carboxyl C & $9.9 \pm 0.4$ & $8.8 \pm 0.9$ \\
Aromatic C & $25.4 \pm 3.3$ & $33.2 \pm 3.6$ \\
Humification ratio & $\mathbf{0 . 9} \pm \mathbf{0 . 1}$ & $\mathbf{0 . 8} \pm \mathbf{0 . 1}$ \\
Aromaticity ratio & $0.4 \pm 0.1$ & $0.6 \pm 0.1$ \\
pH & $7.5 \pm 0.1$ & $7.1 \pm 0.1$ \\
Conductivity / $\mu \mathrm{S} \mathrm{cm}^{-1}$ & $\mathbf{6 9 . 3} \pm \mathbf{4 . 9}$ & $\mathbf{1 3 0 . 5} \pm \mathbf{6 . 4}$ \\
\hline
\end{tabular}

Means in inland and coastal areas $(n=12)$, indicated in bold within each row, are significantly different at $P<0.05$, determined by Fisher's least significant difference (LSD) test.

co-culture (Figure 1b). These changes in CLPP according to the location are associated with the larger functional diversity in the coastal area assessed by the Shannon-Weaver index, $H^{\prime}$, calculated from Biolog data.

The results of the two-way ANOvA support Figure 1(a); they indicate a significant effect of geographical location (Table 1) on the index of functional diversity, $H^{\prime}$, regardless of agricultural practices. This result reveals that the environmental conditions specific to the Mediterranean coastal area have a stronger effect than agriculture practices on soil functional diversity. This is consistent
Table 3 Eigenvalues from the principal component analysis obtained from Biolog data on microbial catabolic profiles of soil

\begin{tabular}{|c|c|c|c|c|c|c|}
\hline & PC1 & PC2 & PC3 & PC4 & PC5 & PC6 \\
\hline Eigenvalue & 0.247 & 0.143 & 0.092 & 0.070 & 0.052 & 0.047 \\
\hline $\begin{array}{l}\text { Percentage variance } \\
\text { explained }\end{array}$ & 29.21 & 16.90 & 10.92 & 8.261 & 6.157 & 5.519 \\
\hline Cumulative / \% & 29.21 & 46.11 & 57.04 & 65.30 & 71.46 & 76.98 \\
\hline
\end{tabular}

with previous research that has shown the significant contribution of micro-local environmental conditions, such as exposure to salinity in coastal environments, to strong functional diversity (Qasemian et al., 2014). Similarly, the selective adaptation of microbial populations to drought and osmotic stresses was responsible for the large functional diversity of microbes in a Greek Mediterranean grassland (Papatheodorou et al., 2004). Climatic conditions in the Mediterranean are known to select thermo-tolerant and drought-resistant microbial communities in soil; these particular conditions act as strong selective environmental factors (Yuste et al., 2014). Another possible explanation for the effect of geographical location on functional diversity is that the agricultural practices applied in olive tree orchards are not intensive. The catabolic evenness of microbial communities depends on the intensity of soil management; soil under long-term arable cultivation is less resistant to osmotic stress than that under pasture (Degens etal., 2001). The way that soil functions under olive tree orchards can be compared with that observed under pasture because soil management practices under olive trees are less intensive than those under long-term cropping (Gómez et al., 2003; Sofo et al., 2005).
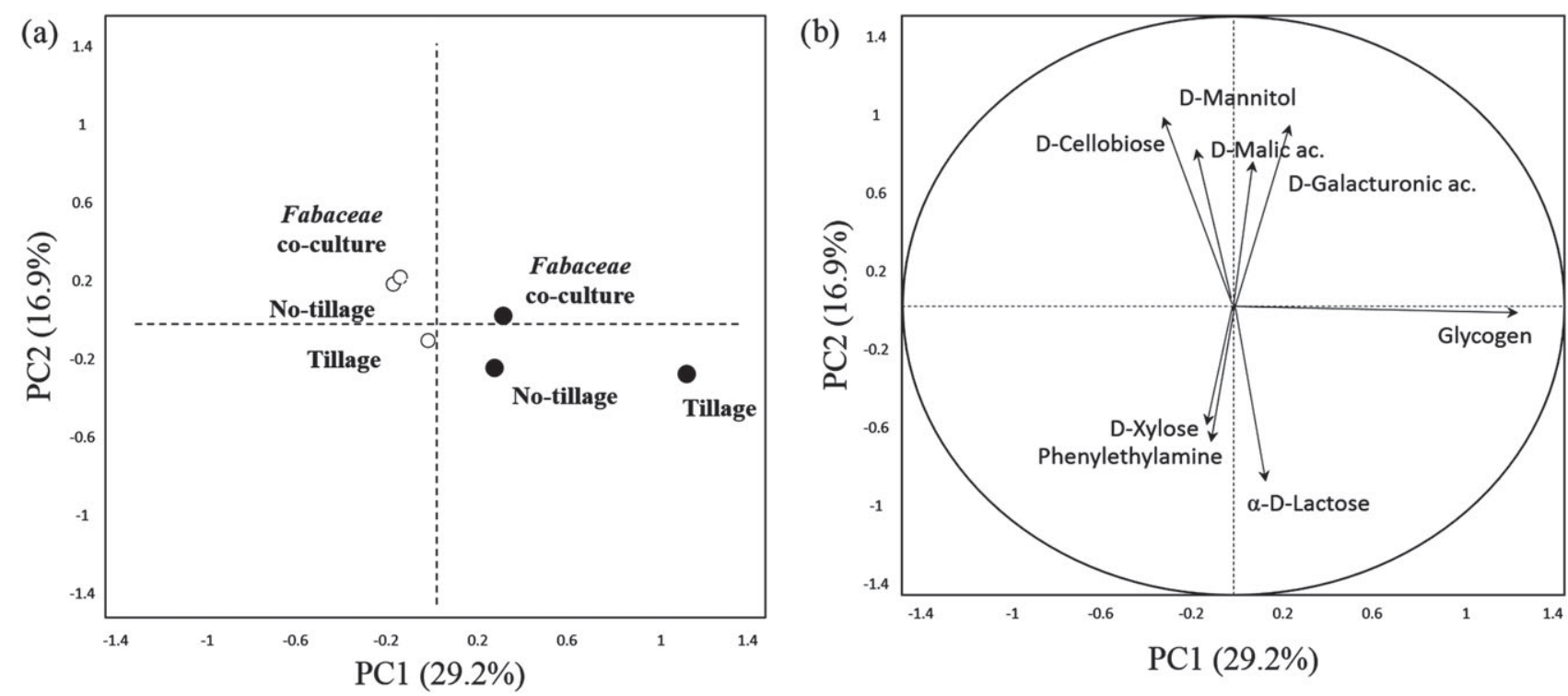

Figure 1 (a) Plot of the principal component analysis (PCA) scores in the plane of PC1 and PC2 obtained from a PCA of microbial catabolic profiles from soil in relation to the agricultural practices selected for both inland (open symbols) and coastal (black symbols) areas and (b) correlation circle of strongly correlated C-substrates (arrows), $r>0.6$. Substrates with stronger correlations $(r>0.5$ or $r<-0.5)$ with PC1 or PC2 were: D-cellobiose $(-0.233$; -0.752$)$, D-mannitol ( $-0.137 ;-0.603)$, D-malic acid $(0.079 ;-0.633)$, D-galacturonic acid $(0.208 ;-0.780)$, D-xylose $(-0.080 ; 0.538)$, phenylethylenamine $(-0.072$; 0.562), $\alpha$-D-lactose $(0.098 ; 0.808)$ and glycogen $(0.997 ; 0.032)$. Centroids (a), representing the average of four replicates, are reported. 

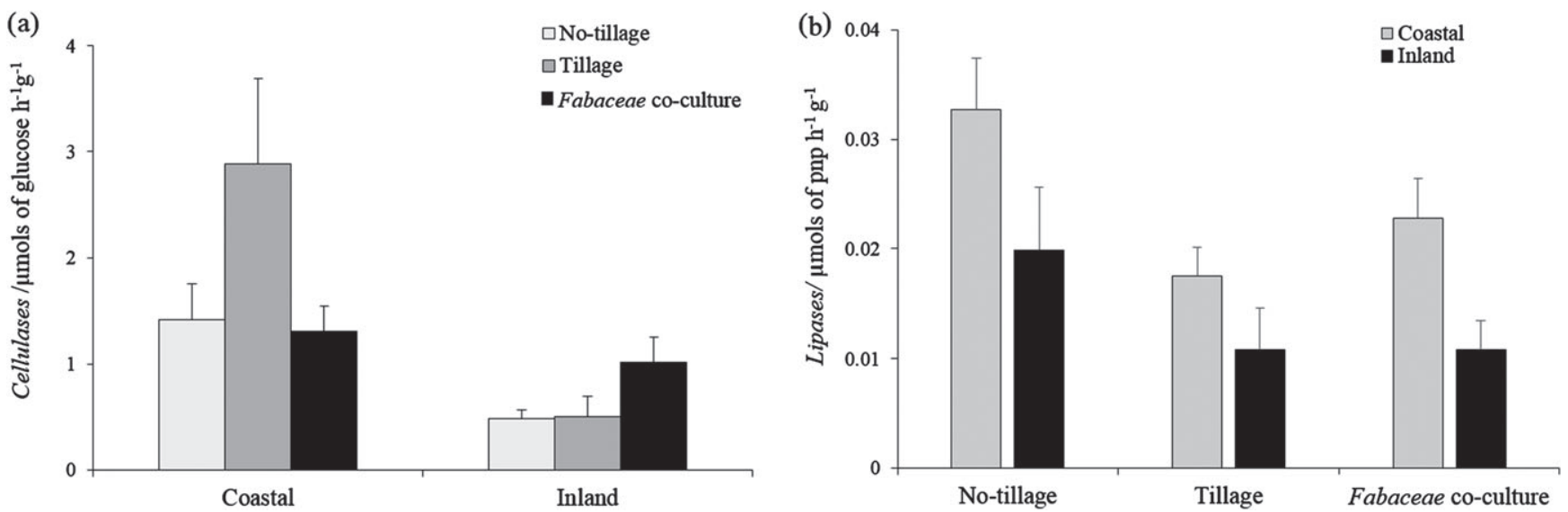

Figure 2 (a) Cellulase and (b) lipase activities of soil sampled from olive orchards under three different agricultural practices in both inland and coastal areas. Bars represent standard errors $(n=4)$.

Figure 1(a) also indicates that PC2 can be explained by the effect of tillage, with both Fabacea co-culture and no-tillage separated from tillage; for the coastal site this separation is along PC1 and for the inland site it is along PC2. Lupwayi et al. (2012) showed that tillage can induce changes in the catabolic potential of soil microbial communities. Conventional tillage disturbs the soil, which results in desiccation, fragmentation of microaggregates (microhabitats that harbour soil microbial biomass and diversity) and long-term compaction (Franzluebbers \& Arshad, 1996). However, modification of the Shannon-Weaver index of diversity did not depend on agricultural practices: a different catabolic structure is evident in the projection in Figure 1(a) by the discrimination between tillage, and no-tillage and Fabaceae for a similar level of functional diversity (assessed by $H^{\prime}$ ). We expected that the different types of agricultural practice selected here would induce specific effects on microbial communities, mainly through organic residue inputs (carbon and nitrogen from Vicia sativa L. var. sativa or natural grass). Greater metabolic diversity in the soil from Mediterranean olive orchards is usually observed because of the organic matter input from self-seeding weeds such as Gramineae L. and Fabaceae Lindley (Sofo et al., 2014). Figure 1(a) indicates a little difference, however, in catabolic structure between cover crops sown after tillage, Fabaceae co-culture, and no-tillage for the inland area because the scores are close to each other (Figure 1a). This result suggests that Vicia sativa L. var. sativa counterbalanced the modifications induced by tillage inland, which led to similar functioning of the soil as when under natural grass. Fabaceae co-culture, therefore, appears to be a good soil management practice to sustain soil quality (Hernández et al., 2005; Gómez et al., 2009, 2011; Nieto et al., 2013), but our results suggest that this is less so near the coast where the soil is under greater stress.

For the other microbial markers under study, one should note that although the $\mathrm{C} / \mathrm{N}$ ratio $(P<0.05)$ was larger in the coastal area, basal respiration $(P>0.05)$ and biomass $(P>0.05)$ were similar in both areas (data not shown). In the coastal area, less depletion of $\mathrm{N}$ and greater microbial catabolic diversity might have enhanced the efficiency of both nitrogen and carbon resource use and consequently sustained microbial respiration (Guénon etal., 2011).

Figure 2(a) shows that the effect of agricultural practices relates to geographical area for cellulase activity; it is larger $(P<0.05)$ in the coastal area, but only after tillage. The effect of agricultural practices on cellulase seemed to be strengthened by the link with geographical location, which shows that mineralization of labile carbon might be enhanced under tillage as described previously by Balesdent et al. (2000). In the coastal environments, tillage favoured the degradation of the major vegetal polymer (i.e. cellulose) in the soil, which consequently induced a loss of soil carbon. Several previous studies have shown that tillage in olive orchards induced the loss of soil organic carbon because of the large rate of mineralization that results from the break-up of soil aggregates; this is a serious threat under Mediterranean conditions (Gómez et al., 2009; Vanwalleghem etal., 2011; Marquez-Garcia etal., 2013). Moreover, we found that lipase activity was greater in non-tilled soil than after tillage in the coastal area (Figure 2b). This result indicates that the recalcitrant fraction of organic matter was actively degraded under natural grass cover. On the other hand, neither urease nor tyrosinase activities (Table 1) were affected regardless of the factor considered (i.e. geographical location, agricultural practices or their interaction). In our research, the effects of agricultural practice appeared to depend mainly on distance from the sea, which suggests the importance of the 'coastal position' (characterized mainly by hydric, thermic and osmotic stresses amplified because of wind conditions and exposure to sea spray) as a controlling factor in the functioning of soil.

\section{Conclusions}

Defining sustainable agriculture is a great challenge, especially in the Mediterranean coastal zones where demographic pressures and human activities are particularly intense. Our study shows that tillage induces negative changes in soil properties (a shift in 
microbial catabolic profile) that can be reduced by cover crops such as Vicia sativa L. var. sativa (catabolic profiles were similar for cover crops sown after tillage and no-tillage). Such cover crops are commonly used under olive trees throughout the circum-Mediterranean region, therefore, they can be considered an appropriate conservation practice to sustain soil functioning in these agrosystems. Furthermore, the effect of tillage depends on the geographical location: coastal-specific constraints seem to increase the effect of soil management on microbial functioning. Thus distance from the sea should be considered when selecting sustainable agricultural practices in Mediterranean countries, and more specifically tillage should not be implemented in olive orchards of the coastal area.

\section{Acknowledgements}

This work was supported financially by a $\mathrm{PhD}$ grant from the National Council for Scientific Research in Lebanon (CNRSL, Beirut, Lebanon). We thank the Center for Remote Sensing for providing environmental data and maps of the areas studied. We would like to thank all the people who helped us with field experiments and technical assistance. This manuscript benefited from the helpful comments of the Editor-in-Chief, the Associate Editor and the three anonymous reviewers. We are very grateful to Marjorie Sweetko and Patrick Fournier for their assistance with the English language.

\section{References}

Anderson, J. \& Domsch, K. 1978. A physiological method for the quantitative measurement of microbial biomass in soils. Soil Biology \& Biochemistry, 10, 215-221.

Baldock, J., Oades, J., Waters, A., Peng, X., Vassallo, A. \& Wilson, M. 1992. Aspects of the chemical structure of soil organic materials as revealed by solid-state ${ }^{13} \mathrm{C}$ NMR spectroscopy. Biogeochemistry, 16, 1-42.

Balesdent, J., Chenu, C. \& Balabane, M. 2000. Relationship of soil organic matter dynamics to physical protection and tillage. Soil \& Tillage Research, 53, 215-230.

Beare, M.H., Neely, C.L., Coleman, D.C. \& Hargrove, W.L. 1990. A substrate-induced respiration (SIR) method for measurement of fungal and bacterial biomass on plant residues. Soil Biology \& Biochemistry, 22, 585-594.

Castro, J., Fernández-Ondoño, E., Rodríguez, C., Lallena, A.M., Sierra, M. \& Aguilar, J. 2008. Effects of different olive-grove management systems on the organic carbon and nitrogen content of the soil in Jaén (Spain). Soil \& Tillage Research, 98, 56-67.

Chalak, L., Noun, J., El Haj, S., Rizk, H., Assi, R., Attieh, J. et al. 2011. Current status of agro-biodiversity in Lebanon and future challenges. Gene Conservation, 10, 23-41.

Darwish, T., Khawlie, M., Jomaa, I., Abou Daher, M., Awad, M., Masri, T. et al. 2006. Digital Soil Map of Lebanon 1/50, 000. Monograph Series No 4. National Council for Scientific Research of Lebanon, Beirut.

Degens, B.P., Schipper, L.A., Sparling, G.P. \& Duncan, L.C. 2001. Is the microbial community in a soil with reduced catabolic diversity less resistant to stress or disturbance? Soil Biology \& Biochemistry, 33, $1143-1153$.
Farnet, A.M., Qasemian, L., Goujard, L., Gil, G., Guiral, D., Ruaudel, F. et al. 2010a. A modified method based on p-nitrophenol assay to quantify hydrolysis activities of lipases in litters. Soil Biology \& Biochemistry, 42, 386-389.

Farnet, A.M., Qasemian, L., Guiral, D. \& Ferré, E. 2010b. A modified method based on arsenomolybdate complex to quantify cellulase activities: application to litters. Pedobiologia, 53, 159-160.

Ferrise, R., Moriondo, M., Trombi, G., Miglietta, F. \& Bindi, M. 2013. Climate change impacts on typical Mediterranean crops and evaluation of adaptation strategies to cope with. In: Regional Assessment of Climate Change in the Mediterranean (eds A. Navarra \& L. Tubiana), pp. 49-70. Springer, Dordrecht.

Franzluebbers, A.J. \& Arshad, M.A. 1996. Water-stable aggregation and organic matter in four soils under conventional and zero tillage. Canadian Journal of Soil Science, 76, 387-393.

Garland, J.L. \& Mills, A.L. 1991. Classification and characterization of heterotrophic microbial communities on the basis of patterns of community-level sole-carbon-source utilization. Applied \& Environmental Microbiology, 57, 2351-2359.

Giorgi, F. \& Lionello, P. 2008. Climate change projections for the Mediterranean region. Global \& Planetary Change, 63, 90-104.

Gómez, J., Battany, M., Renschler, C. \& Fereres, E. 2003. Evaluating the impact of soil management on soil loss in olive orchards. Soil Use and Management, 19, 127-134.

Gómez, J.A., Guzmán, M.G., Giráldez, J.V. \& Fereres, E. 2009. The influence of cover crops and tillage on water and sediment yield, and on nutrient, and organic matter losses in an olive orchard on a sandy loam soil. Soil \& Tillage Research, 106, 137-144.

Gómez, J., Llewellyn, C., Basch, G., Sutton, P., Dyson, J. \& Jones, C. 2011. The effects of cover crops and conventional tillage on soil and runoff loss in vineyards and olive groves in several Mediterranean countries. Soil Use and Management, 27, 502-514.

Guénon, R., Vennetier, M., Dupuy, N., Ziarelli, F. \& Gros, R. 2011. Soil organic matter quality and microbial catabolic functions along a gradient of wildfire history in a Mediterranean ecosystem. Applied Soil Ecology, 48, 81-93.

Hernández, A., Lacasta, C. \& Pastor, J. 2005. Effects of different management practices on soil conservation and soil water in a rainfed olive orchard. Agricultural Water Management, 77, 232-248.

IUSS Working Group WRB. 2006. World Reference Base for Soil Resources 2006. World Soil Resources Report No 103, FAO, Rome.

Kandeler, E. \& Gerber, H. 1988. Short-term assay of soil urease activity using colorimetric determination of ammonium. Biology and Fertility of Soils, 6, 68-72.

Kosmas, C., Danalatos, N., Cammeraat, L.H., Chabart, M., Diamantopoulos, J., Farand, R. et al. 1997. The effect of land use on runoff and soil erosion rates under Mediterranean conditions. Catena, 29, 45-59.

Ladd, J. \& Butler, J. 1972. Short-term assays of soil proteolytic enzyme activities using proteins and dipeptide derivatives as substrates. Soil Biology \& Biochemistry, 4, 19-30.

Lupwayi, N.Z., Lafond, G.P., Ziadi, N. \& Grant, C.A. 2012. Soil microbial response to nitrogen fertilizer and tillage in barley and corn. Soil \& Tillage Research, 118, 139-146.

Marquez-Garcia, F., González-Sánchez, E., Castro-Garcia, S. \& Ordóñez-Fernández, R. 2013. Improvement of soil carbon sink by cover crops in olive orchards under semiarid conditions. Influence of the type of soil and weed. Spanish Journal of Agricultural Research, 11, 335-346. 
Nieto, O.M., Castro, J. \& Fernández-Ondoño, E. 2012. Uso sostenible de suelos de olivar. Efecto del manejo del suelo en sus propiedades. SJSS Spanish Journal of Soil Science, 2, 70-77.

Nieto, O., Castro, J. \& Fernández-Ondoño, E. 2013. Conventional tillage versus cover crops in relation to carbon fixation in Mediterranean olive cultivation. Plant and Soil, 365, 321-335.

Papatheodorou, E., Argyropoulou, M. \& Stamou, G. 2004. The effects of large-and small-scale differences in soil temperature and moisture on bacterial functional diversity and the community of bacterivorous nematodes. Applied Soil Ecology, 25, 37-49.

Qasemian, L., Guiral, D. \& Farnet, A.M. 2014. How do microlocal environmental variations affect microbial activities of a Pinus halepensis litter in a Mediterranean coastal area? Science of the Total Environment, 496, 198-205.

Ramos, M.E., Benítez, E., García, P.A. \& Robles, A.B. 2010. Cover crops under different managements vs. frequent tillage in almond orchards in semiarid conditions: effects on soil quality. Applied Soil Ecology, 44, 6-14.

Saiya-Cork, K., Sinsabaugh, R. \& Zak, D. 2002. The effects of long term nitrogen deposition on extracellular enzyme activity in an Acer saccharum forest soil. Soil Biology \& Biochemistry, 34, 1309-1315.

Shannon, C.E. \& Weaver, W. 1949. The Mathematical Theory of Information. University of Illinois Press, Urbana, IL.

Sofo, A., Nuzzo, V., Palese, A.M., Xiloyannis, C., Celano, G., Zukowskyj, P. et al. 2005. Net $\mathrm{CO}_{2}$ storage in mediterranean olive and peach orchards. Scientia Horticulturae, 107, 17-24.
Sofo, A., Manfreda, S., Fiorentino, M., Dichio, B. \& Xiloyannis, C. 2008. The olive tree: a paradigm for drought tolerance in Mediterranean climates. Hydrology and Earth System Sciences, 12, 293-301.

Sofo, A., Ciarfaglia, A., Scopa, A., Camele, I., Curci, M., Crecchio, C. et al. 2014. Soil microbial diversity and activity in a Mediterranean olive orchard using sustainable agricultural practices. Soil Use and Management, 30, 160-167.

Van Hoorn, J., Katerji, N., Hamdy, A. \& Mastrorilli, M. 2001. Effect of salinity on yield and nitrogen uptake of four grain legumes and on biological nitrogen contribution from the soil. Agricultural Water Management, 51, 87-98.

Vanwalleghem, T., Amate, J.I., de Molina, M.G., Fernández, D.S. \& Gómez, J.A. 2011. Quantifying the effect of historical soil management on soil erosion rates in Mediterranean olive orchards. Agriculture, Ecosystems \& Environment, 142, 341-351.

Yuste, J.C., Fernandez-Gonzalez, A., Fernandez-Lopez, M., Ogaya, R., Penuelas, J., Sardans, J. et al. 2014. Strong functional stability of soil microbial communities under semiarid Mediterranean conditions and subjected to long-term shifts in baseline precipitation. Soil Biology \& Biochemistry, 69, 223-233.

Zak, J.C., Willig, M.R., Moorhead, D.L. \& Wildman, H.G. 1994. Functional diversity of microbial communities: a quantitative approach. Soil Biology \& Biochemistry, 26, 1101-1108. 